\title{
Mycoflora of copra and effect of brining on some properties of copra in Nigeria
}

\author{
Dimkpa, S.O.N. and Onuegbu, B.A.
}

\author{
Dept. of Crop/Soil Science, Rivers State University of Science and Technology, P.M.B 5080, \\ Port harcourt., Nigeria, Corresponding author: dimkpason@yahoo.co.uk \\ ABSTRACT
}

\begin{abstract}
Mycoflora of copra cultivars and effect of brining on the preservation of the product was investigated. Brining at $0,10,20,30$ and $40 \%$ concentrations irrespective of the cultivar, had no significant effect on the total oil contents of the copra, total free fatty acid and iodine value but significantly affected the severity of infection of the mycoflora. Aspergillus niger, ${ }_{2}$ Aspergillus Flavus and Rhizopus stolonifer were isolated from the copra cultivars and were found to reduce total oil content, and increased the free fatty acid and iodine value of the oil, indicating deteriorative processes of the oil. Brining increased the acceptability of the taste but reduced the weights of the copra. Similarly, the acceptability of the physical characteristics was generally reduced by brining irrespective of time and cultivar used. In general, $10 \%$ brine concentration and reduced time of dipping ( 6 hours) appears to hold promise for the preservation of copra. Other recommendations are also addressed.
\end{abstract}

Keywords Aspergillus niger, Aspergillus Flavus, Rhizopus stolonifer, mycoflora, copra, Brining.

\section{INTRODUCTION}

Coconut Cocos nucifera is a very important tree crop grown in many parts of the world. The plant is capable of yielding $60-80$ nuts per palm per year under rain fed conditions and 90-120 nuts per palm per year under irrigated conditions (Phililips, 1974; Rajarajan et al., 2009). Coconut is a perennial oil yielding crop and is mainly grown for the high oil content of the endosperm (copra) which is an important source of vegetable oil used in the manufacturing of edible oils, margarine, cooking fat and soaps (Van Dam, 2005; Rajarajan et al., 2009). Other industrial uses are associated with its products. Soon after Nigerian Independence in 1960, coconut was produced in commercial quantities along the coast of the Niger Delta. However, production of this important crop is presently, in homesteads. Nevertheless, there is an increasing rise in the demand for coconut oil and other coconut products. Total world productivity has increased substantially from 35 million tonnes around 1980 to almost 50 million tonnes today. Yield varies from region to region (3 500 to 6000 nuts/ha/year), which is due to a number of factors (Van Dam, 2005). Poor resource-based farmers smear the copra with common salt after extracting it from the fruit. The effect of this treatment has not been clearly understood. This research therefore aims at:

1. Isolating the mycoflora of copra grown in Port Harcourt area of Nigeria.
2. Investigating the effects of brining on some properties of the copra.

This work will contribute immensely on the preservation of copra in coconut producing countries of the world.

\section{MATERIALS AND METHODS}

Matured coconut fruits were collected from coconut palms grown in Port Harcourt, Nigeria. Two cultivars of coconut, Dwarf Yellow type and West African Tall Green type, were used.

Isolation of mycoflora of copra: The copra was extracted from the coconuts and the mycoflora associated with them was isolated using the standard Blotter (Scottie Tissue) method. The copra (meat) was sliced into small pieces $\left(5 \times 5 \mathrm{~mm}^{2}\right)$ and plated in Petri dishes containing moist, sterile No. 1 Whatman paper. They were incubated at $27 \pm 2^{\circ} \mathrm{C}$ for 7 days in an incubator. The growing fungi were identified on the basis of colour of hyphae, shapes of the spores and morphology of the mycelium produced, using light microscope. The percentage incidence of the fungi was calculated as the frequency of the individual fungus growing on the slices divided by the total number of slices assessed multiplied by 100 . These were repeated for the two slices and the experiment was replicated 3 times.

Pure cultures of the fungi were prepared by means of Potato Dextrose Agar (P.D.A.) and were preserved in the refrigerator for future use. 
Effect of fungi on some biochemical characteristics of Copra: The slices of each cultivar were respectively inoculated with the isolated fungi. This was done by dipping surface-sterilised copra slices $(5 \times 5 \mathrm{~cm}$ each) into fungal suspension produced by homogenising 5 discs of each fungus in $10 \mathrm{ml}$ sterile distilled water. The slices in sterile Petri dishes incubated at $27 \pm 2^{\circ} \mathrm{C}$ in an incubator for 7 days. Dipping the slices in sterile distilled water served as control.

The total oil content, free fatty acid (f.f.a) and the iodine value of the infected and uninfected samples of each cultivar were analysed. The total lipids per $5 \mathrm{~g}$ dry weight were analysed by the soxhlet method of extraction (Block, 1956) while the free fatty acid was assessed by Titrimetric method of (BS 684:1958; BS $627: 1965) .1 .5 \mathrm{~g}$ of the oil sample was titrated with 0.IN Sodium hydroxide using phenolphthalein as the indicator. The free fatty acid (f.f.a) was calculated from the formula.

$\%$ F.F.A. $=\quad$ Titre value $X$ Normality of the base $X$ Molecular weight of the fatty acid $\times 100$ Wt. of sample $\times 1000$

The lodine Value was analysed using Wijis method (BS 684,1958) and calculated using the formula:

$$
\text { Iodine Value }=\frac{(\mathrm{b}-\mathrm{a}) \times 1.269}{\text { Wt. of Sample }(\mathrm{g}) .}
$$$$
\text { Where } \mathrm{b}=\text { blank }
$$

$$
a=\text { the main titration }
$$

Effect of Brining on some properties of Copra: The slices of the Copra were separately dipped in $0 \%, 10 \%, 20,30$ and $40 \%$ solution of sodium chloride (common salt) at different trimming $(0,6,12,18$ and 24 hours, respectively). Five slices of each of the brined cultivars were separately inoculated with the fungi isolates as earlier explained. The severity of infection was assessed after 7 days using the following infection ratings:

$\begin{array}{lll}\text { No. Rot } & = & 0 \\ \text { Slight Decay } & = & 1 \\ \text { High Decay } & = & 2\end{array}$

Total loss of coherence $=3$

These ratings were converted into Disease Indices (DI) ranging from zero to 3 . The total lipids, free fatty acids and lodine Value of the uninoculated copra dipped in difference brine concentrations and at different periods of dipping were analysed as earlier explained. Similarly, the weight of the treated samples was also measured using the chemical balance.

In related experiments, the taste characteristics of the brined samples were studied by involving 10 students who ate and ranked the meat using the following 4point Hedonic scale:

Not salty and unacceptable $=1$ Salty and unacceptable $=2$ Salty and acceptable $\quad=3$ Salty and Excellent = 4

A mean of the scores was recorded for each brine concentration and cultivar.

Similarly, the physical characteristics of the dipped copra were also studied using a hand lens and scored using the 6-point Hedonic scale:

$\begin{array}{lll}\text { Very smooth } & = & 6 \\ \text { Smooth } & = & 5 \\ \text { Moderately smooth } & = & 4 \\ \text { Moderately rough } & = & 3 \\ \text { Rough } & = & 2 \\ \text { Very Rough } & = & 1\end{array}$

A mean of the scores (Acceptability Index) was recorded for each brine solution and cultivar.

The experimental design was a Factorial in Completely Randomised Design (CRD). The results were analysed by means of analysis of variance (ANOVA).

\section{RESULTS AND DISCUSSION}

The results of investigations on the mycoflora of copra and the effects of brining on some of the properties of copra are shown in Tables 1 and 2 . Table 1 shows the incidence of fungal flora of copra and indicates that Aspergillus niger ${ }_{1}$ A. Flavus and Rhizopus stolonifer were implicated in the deterioration of copra obtained in Port Harcourt area of Nigeria. R. Stolonifer had highest frequency of occurrence in the orange cultivar.

Table 1: Fungal incidence in copra and their effect on some of the biochemical properties of copra.

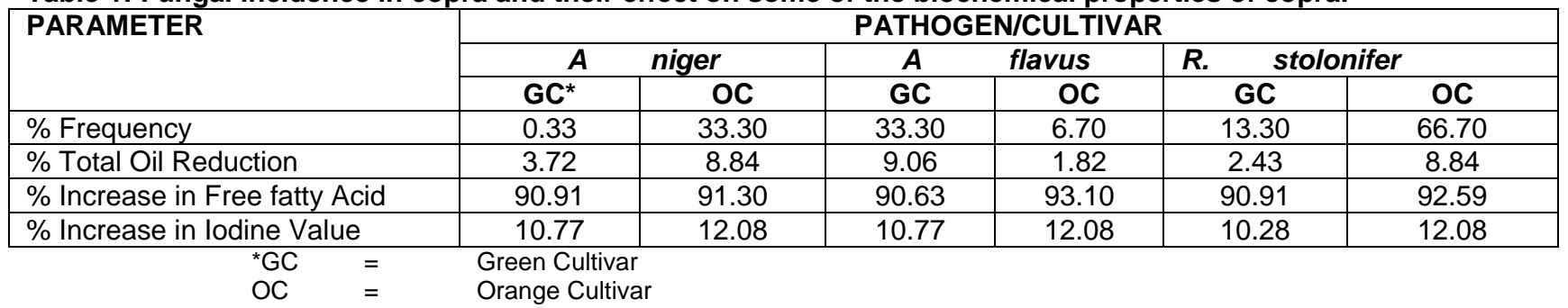


Agric. Biol. J. N. Am., 2010, 1(3): 391-394

Table 2. Effect of different concentrations of common salt on some characteristics of two cultivars copra

\begin{tabular}{|c|c|c|c|c|c|c|c|c|c|c|c|c|c|c|c|c|c|c|c|c|}
\hline \multirow{3}{*}{$\begin{array}{l}\text { BRINE } \\
\text { CONC } \\
\cdot \\
\text { (\%) }\end{array}$} & \multirow{3}{*}{\multicolumn{2}{|c|}{$\begin{array}{l}\text { TIME OF } \\
\text { DIPPING } \\
\text { (HRS) }\end{array}$}} & \multirow{2}{*}{\multicolumn{2}{|c|}{$\begin{array}{c}\text { TASTE } \\
\text { CHARACTERISTICS } \\
\text { (TI) }\end{array}$}} & \multirow{2}{*}{\multicolumn{2}{|c|}{$\begin{array}{c}\text { PHYSICAL } \\
\text { CHARACTERISTICS } \\
\text { (AI) } * *\end{array}$}} & \multirow{2}{*}{\multicolumn{2}{|c|}{$\begin{array}{l}\text { WEIGHT } \\
\text { (g) }\end{array}$}} & \multirow{2}{*}{\multicolumn{2}{|c|}{$\begin{array}{c}\text { TOTAL OIL/0.5C } \\
\text { SAMPLE (\%) }\end{array}$}} & \multirow{2}{*}{\multicolumn{2}{|c|}{$\begin{array}{c}\text { TOTAL } \\
\text { FFA/1.5g } \\
\text { SAMPLE (\%) }\end{array}$}} & \multirow{2}{*}{\multicolumn{2}{|c|}{$\begin{array}{c}\text { IODINE VALUEI } \\
0.6 \mathrm{~g} \text { SAMPLE }\end{array}$}} & \multicolumn{6}{|c|}{ SEVERITY OF INFECTION } \\
\hline & & & & & & & & & & & & & & & \multicolumn{2}{|c|}{ A. niger ** } & \multicolumn{2}{|c|}{ A. flavus ** } & \multicolumn{2}{|c|}{ R.Stolonfer ** } \\
\hline & & & GC & OC & GC & OC & GC & OC & GC & OC & GC & & GC & & GC & OC & GC & OC & GC & OC \\
\hline \multirow[b]{3}{*}{0} & 0 & & 1.00 & 1.00 & 5.00 & 5.00 & 0.70 & 0.60 & 56.00 & 66.00 & 3.50 & 2.70 & 87.90 & 87.00 & 12.67 & 15.00 & 10.33 & 15.00 & 12.67 & 15.00 \\
\hline & 6 & & 1.00 & 1.00 & 4.33 & 4.33 & 0.80 & 0.87 & 57.30 & 68.00 & 3.50 & 2.83 & 87.90 & 87.00 & 9.67 & 12.67 & 3.33 & 12.67 & 12.67 & 15.00 \\
\hline & 12 & & 1.00 & 1.00 & 4.00 & 3.67 & 0.70 & 1.17 & 61.00 & 60.00 & 3.30 & 3.50 & 88.00 & 88.10 & 12.00 & 9.67 & 5.33 & 9.67 & 15.00 & 15.00 \\
\hline & & & & & & & & & & & & & & & & & & & & \\
\hline & 18 & & 1.00 & 1.00 & 3.33 & 3.33 & 0.90 & 0.90 & 60.00 & 65.40 & 3.30 & 2.80 & 88.00 & 87.10 & 10.33 & 12.00 & 6.33 & 6.67 & 10.33 & 15.00 \\
\hline & 24 & & 1.00 & 1.00 & 3.33 & 3.33 & 0.57 & 0.53 & 61.00 & 66.00 & 3.40 & 2.90 & 88.10 & 87.00 & 10.67 & 9.67 & 7.67 & 12.00 & 15.00 & 15.00 \\
\hline \multirow{5}{*}{10} & 0 & & 2.67 & 2.67 & 4.67 & 4.67 & 0.70 & 0.50 & 59.80 & 60.00 & 3.50 & 2.79 & 88.10 & 87.30 & 12.67 & 9.67 & 5.00 & 10.33 & 12.67 & 12.67 \\
\hline & 6 & & 4.00 & 2.67 & 3.67 & 3.67 & 0.70 & 0.77 & 60.20 & 59.00 & 3.20 & 2.75 & 88.10 & 86.80 & 7.33 & 8.33 & 4.67 & 7.33 & 15.00 & 6.67 \\
\hline & 12 & & 3.67 & 3.33 & 3.33 & 2.00 & 0.57 & 0.90 & 60.00 & 68.00 & 3.40 & 2.80 & 88.10 & 87.30 & 9.67 & 5.33 & 3.00 & 5.33 & 10.33 & 6.00 \\
\hline & 18 & & 3.67 & 3.67 & 3.33 & 2.00 & 0.83 & 0.67 & 59.00 & 70.00 & 3.50 & 2.80 & 88.20 & 87.30 & 5.67 & 4.00 & 3.00 & 8.33 & 12.67 & 12.00 \\
\hline & 24 & & 3.67 & 4.00 & 3.00 & 2.00 & 0.43 & 0.60 & 58.00 & 64.00 & 3.50 & 2.90 & 88.20 & 87.30 & 8.00 & 3.38 & 3.33 & 6.00 & 7.33 & 12.67 \\
\hline \multirow{5}{*}{20} & 0 & & 3.33 & 3.33 & 4.00 & 4.00 & 0.87 & 0.23 & 60.00 & 70.00 & 3.30 & 3.30 & 88.40 & 86.90 & 9.67 & 12.67 & 5.33 & 15.00 & 12.00 & 15.00 \\
\hline & 6 & & 3.67 & 3.00 & 3.00 & 2.67 & 0.67 & 0.53 & 59.00 & 65.00 & 3.40 & 2.70 & 88.60 & 86.90 & 12.00 & 9.67 & 2.00 & 5.33 & 9.67 & 15.00 \\
\hline & 12 & & 4.00 & 3.33 & 2.67 & 2.67 & 0.63 & 0.67 & 55.00 & 66.00 & 3.50 & 2.80 & 88.40 & 86.90 & 8.00 & 4.67 & 1.33 & 2.00 & 12.00 & 12.67 \\
\hline & 18 & & 3.67 & 3.33 & 2.33 & 2.00 & 0.87 & 0.50 & 57.80 & 65.80 & 3.30 & 2.90 & 88.60 & 86.90 & 8.33 & 4.67 & 1.00 & 1.00 & 7.67 & 7.67 \\
\hline & 24 & & 3.00 & 2.67 & 3.00 & 1.67 & 0.53 & 0.47 & 59.00 & 68.00 & 3.50 & 2.90 & 88.30 & 86.90 & 6.67 & 2.00 & 1.00 & 1.00 & 5.33 & 9.67 \\
\hline \multirow{5}{*}{30} & 0 & & 3.33 & 3.67 & 4.00 & 4.00 & 0.90 & 0.63 & 59.20 & 66.00 & 3.50 & 2.80 & 88.20 & 87.10 & 9.00 & 15.00 & 4.00 & 12.00 & 12.67 & 15.00 \\
\hline & 6 & & 3.67 & 3.67 & 2.67 & 2.67 & 0.43 & 0.57 & 54.00 & 64.00 & 3.50 & 2.87 & 88.20 & 87.10 & 9.67 & 3.33 & 1.67 & 4.67 & 6.67 & 12.67 \\
\hline & 12 & & 3.33 & 2.33 & 2.33 & 2.00 & 0.53 & 0.53 & 57.80 & 70.00 & 3.40 & 2.90 & 88.20 & 87.10 & 7.67 & 2.00 & 1.33 & 1.67 & 2.67 & 6.67 \\
\hline & 18 & & 3.33 & 2.67 & 2.00 & 2.00 & 0.70 & 0.57 & 60.20 & 67.20 & 2.70 & 2.70 & 88.20 & 87.10 & 4.00 & 1.67 & 1.33 & 1.33 & 1.33 & 7.67 \\
\hline & 24 & & 3.33 & 2.67 & 1.67 & 1.67 & 0.60 & 0.20 & 58.00 & 64.60 & 3.60 & 2.90 & 88.10 & 87.10 & 3.00 & 1.33 & 1.00 & 1.00 & 1.33 & 5.33 \\
\hline \multirow{5}{*}{40} & 0 & & 3.00 & 3.00 & 4.00 & 4.00 & 0.83 & 0.70 & 61.00 & 68.20 & 3.50 & 2.80 & 88.00 & 85.90 & 4.67 & 6.67 & 3.33 & 4.67 & 15.00 & 15.00 \\
\hline & 6 & & 2.67 & 3.00 & 2.67 & 2.33 & 0.43 & 0.30 & 60.20 & 60.20 & 3.50 & 2.70 & 88.10 & 86.90 & 2.00 & 2.00 & 2.00 & 1.67 & 6.67 & 9.00 \\
\hline & 12 & & 3.00 & 2.33 & 2.00 & 1.67 & 0.47 & 0.67 & 57.80 & 68.80 & 3.50 & 2.80 & 88.00 & 87.10 & 1.67 & 1.67 & 1.33 & 1.33 & 1.00 & 6.67 \\
\hline & 18 & & 2.00 & 2.00 & 2.00 & 1.67 & 0.60 & 0.37 & 60.40 & 67.80 & 3.40 & 2.80 & 88.20 & 86.90 & 1.33 & 1.67 & 1.00 & 1.33 & 1.33 & 9.67 \\
\hline & 24 & & 2.00 & 2.67 & 1.33 & 1.33 & 0.47 & 0.37 & 61.00 & 65.80 & 3.50 & 2.90 & 88.10 & 86.90 & 1.00 & 1.33 & 1.00 & 1.00 & 0.67 & 4.33 \\
\hline
\end{tabular}


(66.70\%) followed by $A$. niger (33.30\%) and least in A. flavus. However, A. flavus was highest in the green cultivar (33.30\%) followed by $R$. stolonifer (13.30\%) while $A$. niger was not isolated from the green cultivar. Nevertheless, pathogenicity studies indicated that the three fungi were pathogenic to the copra irrespective of the cultivar. Similarly, the research suggests that the fungal pathogens may show preference for cultivar. Apart from the incidence of $R$. stolonifer on the orange cultivar, the occurrence of the fungi in copra might not, at present, be a serious threat to copra production but where they occur, they might reduce the oil content of the copra and as well render the remaining fraction inedible. There was a general reduction in oil contents of the copra irrespective of the cultivar. This agrees with the findings of Nair et al. (1981).

The highest reduction was caused by $A$. flavus in the green cultivar followed by $R$. stolonifer and $A$. niger in the orange cultivar and least in $A$. flavus in the orange cultivar. Similarly, there was a general increase in the free fatty acid (f.f.a) of the copra indicating the oxidation and alteration of the oil quality by the fungi resulting in the production of unpleasant taste and odour (rancidity). This was confirmed by a general increase in the lodine Value of the oil indicating the oxidation and degradation of the unsaturated fatty acids of the oil.

The effect of brining on some characteristics of copra is shown in Table 2 . Brining generally reduced the severity of infection of the copra by the fungi irrespective of time of dipping and concentration. However, the decrease in severity decreased with concentration of the brine solution. Higher concentrations, however, roughened the surface of the copra but $10 \%$ concentration of brine showed moderate roughness on the surface of the copra and were also acceptable in terms of taste irrespective of the cultivar. Similarly, there was a progressive decrease in weight of the copra as the time of dipping and concentration increased. Dipping for 6 hours in $10 \%$ concentration is recommended from the findings of this work. Brining did not significantly affect the total oil content of copra irrespective of time of dipping and concentration. Similarly, total free fatty acid was not significantly affected. Onuegbu and Ihuanne (1994) showed a reduction in growth of $A$. niger, Penicillium spp. And Clalosphorium sp., isolated from palm oil, by common salt. Similarly,
Surono et al. (1994) reported the conservation of nutrients in prickle salt and saturated brining procedure. These reports agree with the findings of this research. This work shows that common salt could preserve copra while inhibiting the growth of fungi spoilage micro-organisms.

\section{CONCLUSION}

The dipping of copra into brine solution reduced the growth of fungal spoilage organisms, helping in its preservation. Lower concentrations (10\%) and reduced time of dipping (6 hours) are recommended in order to have an acceptable taste of the copra, moderate roughness of the skin of the copra and the desired weight. In general brining does not significantly affect the oil content of the copra.

\section{REFERENCES}

Block, (1956),: Lipid synthesis in Hansennula anomala. Mycologia 48:331-343.

British System (BS) (1958) P. 684.

British System (BS) (1965) P. 627.

Nair, P.K., Unnikrishnan, J., Samra J. and Wilson, K. (1981). Deterioration of copra by fungi. Indian Journal Res. 15 (2): 99-102.

Onuegbu, B.A and Ihuanne, H.A. (1994). Effect of Common salt on stored oil of oil palm Elaeis guineensis. Indian J. Agric. Sci. 64(9): 647-649.

Philips, T.A (1974). An Agricultural Notebook. Longmans Ltd London, 50pp.

Surono, K.D., Anthony, T., and Gillan, Smith (1991). The effect of different salting procedures and qualities of raw materials on some nutrients during and after storage of salted dried mackerel. International J. of food science and Tech. 29, 179-183.

Rajarajan, G., Sureshkumar S., Rajkala A. (2009). Effect of enriched organic waste on available nutrients in soil and yield of coconut trees. Published by the national law school of India University (NLSIU) Centre for Environmental law Education Research and Advocacy (CEERA). 10:12p

Van Dam, J.E.G. (2005). Coir Processing Technologies Improvement of Drying, Softening, Bleaching and Dyeing Coir Fibre/Yarn and Printing Coir Floor Coverings. Department of Fibres and Cellulose Agrotechnological Research Institute(ATO bv) Wageningen, the Netherlands. Technical Paper No. 6 